\title{
A rapid and simple method for detection of type II restriction endonucleases in cells of bacteria with high activity of nonspecific nucleases
}

\author{
Beata Podgórska1,2凶, Grażyna Kujawska², Michał Skurzewski², Olesya Batsko² \\ and Tadeusz Kaczorowski²
}

1Department of Molecular Evolution, 2Department of Microbiology, University of Gdańsk, Gdańsk, Poland

In this work we describe a novel, rapid and simple microscale procedure for identification of restriction endonuclease activity in bacteria lysates, which contain high levels of non-specific DNA nucleases.

Key words: bacteria screening, site-specific endonuclease purification, type II restriction endonuclease

Received: 23 July, 2012; revised: 16 October, 2012; accepted:

29 October, 2012; available on-line: 06 November, 2012

\section{INTRODUCTION}

Restriction endonucleases are found in many Prokaryota, mainly bacteria (Bickle \& Krüger, 1993). They are part of the restriction-modification system which also comprises methyltransferase activity. It is generally considered that their principal biological function is host genome protection against foreign, in particular bacteriophage, DNA (Arber, 1979; Krüger et al., 1983).

Type II restriction endonucleases require $\mathrm{Mg}^{2+}$ to cleave DNA. They recognize double stranded DNA at palindromic sequences and cleave it at specific sites within or adjacent to their recognition sequences (Pingoud \& Jeltsh, 2001).

Site-specific type II endonucleases are utilised in a wide variety of applications (Roberts, 2005). They are important tools in recombinant DNA technology, gene engineering, mapping of genomes and medical diagnostics. Because of their broad applications, the isolation of novel restriction endonucleases is in demand.

Usually, the first step in the production of new commercially useful restriction endonucleases is bacteria screening. It is very important to choose an adequate, easy, quick and highly sensitive method that can provide screening for a large number of strains.

One of the methods that meets these conditions is the one described by Belavin et al. (1988). This method allows one to detect the presence of a restriction endonuclease activity in lysates from a single bacterial colony. The bacterial cell walls are disrupted by lysing buffer and the cell-free extract is scanned for the enzyme activity.

This method is usually satisfactory, but fails when high activities of non-specific DNA-degrading nucleases are present in the bacterial lysates. Their presence is the main limiting factor for the successful isolation of restriction endonucleases and their prior removal is necessary (Poch \& Somkuti, 1993; 1995; Puchkova et al., 2002).

Conventionally, restriction endonucleases can be purified by column chromatography on a variety of matri- ces (Whitehead et al., 1985; Kaida et al., 1999). However, these methods require the use of large volumes of both bacterial culture and chromatography matrix (Greene et al., 1978; Smith et al., 1976), which makes them costly, timeconsuming and thus not useful for bacteria screening.

This work describes a quick and simple microscale procedure for preliminary identification of restriction endonuclease activity in lysates of Enterobacteriaceae, which are known to contain relatively high levels of nonspecific DNA nucleases. However, our unpublished result indicate that it is universally applicable to a wide variety of bacteria.

\section{MATERIALS AND METHODS}

Bacterial strains, culture conditions and identification. Strains of Enterobacteriaceae were isolated from sewage samples obtained from the Gdańsk-Wschód Mechanical-Biological Sewage Treatment Plant as well as biological materials from patients of The Mikołaj Kopernik State Hospital in Koszalin, where they were identified according to Isenberg (2007).

Isolation, characterization and primary analysis of Enterobacteriaceae from sewage samples were performed on MacConkey agar (Emapol). Both lactose positive and negative bacterial colonies were selected for further tests. Gram staining (Gram PVP kit; Graso) and cytochrome oxidase test (BioMerieux) were performed to exclude other Gram negative but non-fermenting bacilli.

Detailed identification of bacterial strains was performed using Microgen GN-ID test (Graso) (Edberg et al., 1979) and Api 20E test (BioMerieux) (Edwards \& Ewing, 1972).

Short characteristics of the microbial strains tested is presented in Table 1.

Single bacterial colonies from MacConkey agar were taken to isolate cell lysates according to Belavin et al. (1988). To isolate cell lysates by sonication, single bacterial colonies were further cultured for $24 \mathrm{~h}$ in $100-\mathrm{ml}$ Erlemayer flask containg $20 \mathrm{ml}$ of Luria-Bertani (LB) medium, at $37^{\circ} \mathrm{C}$ with shaking.

Preparation of the cell-free extract. To prepare cell free extract according to the Belavin et al. (1988) protocol, a single bacterial colony was taken from agar plate and transferred into $40 \mu \mathrm{l}$ of lysing buffer $(100 \mathrm{mM}$

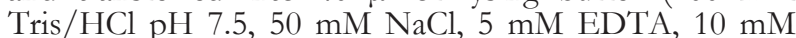
$\beta$-mercaptoethanol, $0.1 \%$ Triton X-100 and freshly pre-

e-mail: beata.podgorska@biol.ug.edu.pl Abbreviations: LB, Luria-Bertani medium 
Table 1. Characteristics of restriction endonuclease-producing bacteria

\begin{tabular}{lllll}
\hline Strain & Strain origin & Izoschizomer of & Lactose on MacConkey agar & Urease \\
\hline Escherichia coli & hospital & EcoRV & + & + \\
Escherichia vulneris & hospital & EcoVIII & - & - \\
Citrobacter freundii & sewage & BspEl & + & - \\
Klebsiella pneumoniae & sewage & BstEll & + & - \\
\hline
\end{tabular}

pared lysozyme $0.1 \mathrm{~g} / 1$ (Sigma)). The mixture was incubated for 15-30 min. at room temperature with periodic shaking.

To prepare cell free extract by sonication, $20 \mathrm{ml}$ of bacterial culture was centrifuged at $4000 \times g$ for $10 \mathrm{~min}$. Cells were washed twice with $10 \mathrm{mM} \mathrm{K} / \mathrm{PO}_{4}$ buffer $\mathrm{pH}$ 7.0 (Sambrook et al., 1989) (10 mM K/PO, $10 \mathrm{mM} \mathrm{KCl,}$ $1 \mathrm{mM}$ EDTA, $10 \mathrm{mM} \beta$-mercaptoethanol, $5 \%$ glycerol), resuspended in $3 \mathrm{ml}$ of sonication buffer $(10 \mathrm{mM} \mathrm{K} /$ $\mathrm{PO}_{4}, \mathrm{pH}$ 7.0, 1 mM EDTA, $10 \mathrm{mM} \beta$-mercaptoethanol, $15 \mathrm{mM}$ phenylmethylsulfonyl fluoride (PMSF), 5\% glycerol) and disintegrated by sonication at $4^{\circ} \mathrm{C}$ in an ice bath, with $30 \times 10$-second pulses with one-minute intervals at an amplitude of $12 \mathrm{~mm}$.

Partial purification of restriction endonucleases from bacterial cell free extracts. Bacterial cell free extracts obtained by sonication or the Belavin et al. (1988) method were centrifuged at $15000 \times \mathrm{g}$ for $30 \mathrm{~min}$ at $4^{\circ} \mathrm{C}$ to remove cells debris. Supernatant was loaded on recycled plasmid mini kit $\mathrm{V}$-spin columns (the ones from A\&A Biotechnology were used, but it is possible to use mini columns from another company). The exploited silica-based layer was removed from the glass fiber column and replaced with one of the following chromatography matrices: phosphocellulose P-11 (Whatman), heparinsepharose (Sigma Aldrich), CM sephadex C-50 (Pharmacia) (cation exchangers), or blue-agarose (Pharmacia) (affinity medium). The columns were filled with $250 \mu \mathrm{l}$ of a chromatography matrix for purification of the extracts obtained by Belavin method and $1.0 \mathrm{ml}$ for the extracts obtained by sonication. They were washed with $3 \times$ column volume of ice-cold $10 \mathrm{mM} \mathrm{K} / \mathrm{PO}_{4}(\mathrm{pH} 7.0)$ buffer. To elute proteins, a stepwise gradient of $0.2-1.0$ $\mathrm{M} \mathrm{KCl}(0.2 \mathrm{M}$ increments) was used and $50 \mu \mathrm{l}$ (from columns with $250 \mu \mathrm{l}$ of chromatography matrix) or 100 $\mu \mathrm{l}$ fractions (from columns with $1 \mathrm{ml}$ of chromatography matrix) were collected after 30 s. $500 \times g$ centrifugation at $4^{\circ} \mathrm{C}$. Each fraction was assayed for restriction endonuclease activity as described below.

Endonuclease activity assay. Either the crude bacterial extracts obtained by Belavin et al. method (1988) and sonication, or the individual fractions eluted from the chromatography column were added to bacteriophage $\lambda$ DNA. The digestion was performed for $15-30$ min. at $37^{\circ} \mathrm{C}$ in a total of $20 \mu \mathrm{l}$ reaction mixture of the following composition: $2 \mu \mathrm{l}$ of the protein extract, $2 \mu \mathrm{l}$ of $10 \times$ yellow Tango ${ }^{\text {TM }}$ buffer (Fermentas) $(330 \mathrm{mM}$ Tris-acetate $\mathrm{pH} 7.9,100 \mathrm{mM}$ Mg-acetate, $660 \mathrm{mM} \mathrm{K}$ acetate, $0.1 \mathrm{mg} / \mathrm{ml} \mathrm{BSA}), 1 \mu \mathrm{g}$ of $\lambda$ DNA substrate and $15 \mu \mathrm{l}$ of sterile $\mathrm{dH}_{2} \mathrm{O}$.

The presence of site-specific DNase activity was determined on $1 \%$ agarose gel containing $0.5 \mu \mathrm{g} / \mathrm{ml}$ of ethidium bromide, in TBE buffer. The recognition of the restriction endonuclease activity was first established by a comparison of the pattern of digestion with the NEBcutter V2.0 database (New England BioLabs, http://rebase.neb.com/rebase/rebase.html) and followed by comparison of the digest with those of commercially available enzymes.

\section{RESULTS AND DISCUSSION}

A major problem that occurs during screening for restriction endonucleases is the presence of nonspecific nucleases in bacterial cells. Their prior removal is advised, as they may mask the presence of restriction endonucleases. We have developed a simple, rapid and low cost method to address this problem.

In the method described here, we used recycled plasmid mini kit V-spin columns, with the silica-based layer removed and replaced with a small volume of a chromatography matrix. Bound proteins were eluted with a stepwise gradient of $\mathrm{KCl}$ and the samples were collected by centrifugation.

This method allows one to obtain, within just several minutes, lysate samples purified enough to unmask determine the activity of site-specific endonucleases. Each eluted sample was assayed immediately for the presence of a restriction endonuclease activity by digestion of bacteriophage $\lambda$ DNA. The endonucleases from individual column fractions remained active for two weeks (data not shown).

In this experiment we used a strain of E. coli expressing HindIII endonuclease (Mruk \& Kaczorowski, 2003). The cell free extracts obtained with lysing buffer (Fig. 1A, lane 1) as well as sonication (Fig. 1A, lane 2) are rich in non-specific nucleases precluding the visualisation of the site-specific activity. The cell free extracts were purified on mini-columns with phosphocellulose P-11 in accordance with the method described in detail above. Results of the purification are shown in Fig. 1B and $\mathrm{C}$.

The use of phosphocellulose P-11 removed some of the nonspecific endonucleases from the bacterial lysates

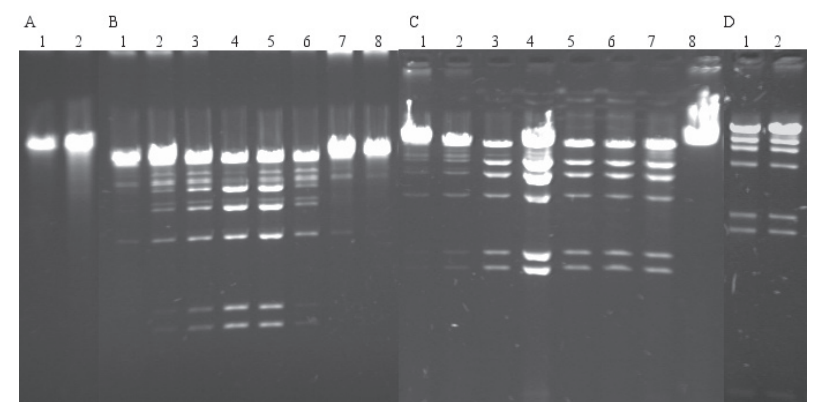

Figure 1. Products of bacteriophage I DNA digestion.

(A) crude $E$. coli extract with Hindlll activity obtained by: 1) Belavin method, 2) sonication. (B) extract obtained by Belavin method after phosphocellulose purification (nonspecific bands are visible, probably due to inefficient removal of nonspecific nucleases) (C) extract obtained by sonication after phosphocellulose purification (nonspecific nucleases were removed, hence specific bands are present and I DNA/HindIII endonuclease digestion pattern is clear; lane 5, 6,7 specific bands; lane 1,2,3,4,8, presence of unspecific bands). (B) and (C) Hindlll eluted with various concentrations of $\mathrm{KCl}$ (lanes: $10.2 \mathrm{M}$; 2,3 $0.4 \mathrm{M}$; 4,5 0.6 M; 6,7 $0.8 \mathrm{M} ; 8$ 1.0 M). (D) bacteriophage I DNA digestion pattern obtained by: 1) commercial enzyme 2) sonicate after phosphocellulose purification (0.8 M $\mathrm{KCl}$ elution fraction). 


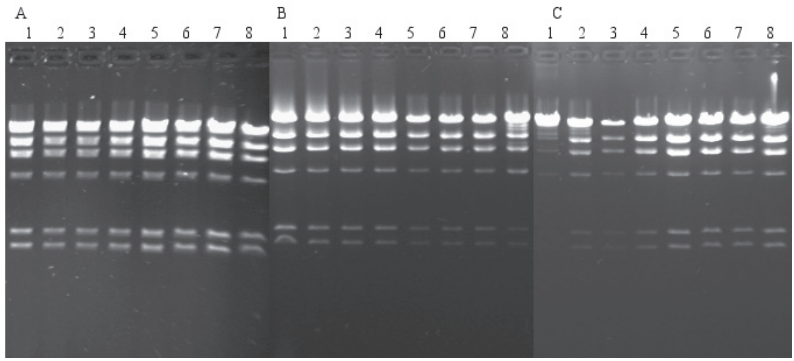

Figure 2. Patterns of bacteriophage I DNA digestion with sonicated extract of $E$. coli with HindIII activity after purification on

(A) blue-agarose, (B) heparin-sepharose, (C) sephadex C-50 and elution with various concentrations of $\mathrm{KCl}$. Lanes: $1-0.2 \mathrm{M} ; 2,3$ $-0.4 \mathrm{M} ; 4,5-0.6 \mathrm{M} ; 6,7-0.8 \mathrm{M} ; 8-1.0 \mathrm{M}$.

obtained according to Belavin et al. (1988). After digestion of $\lambda$ DNA, nonspecific bands were observed in each lane (Fig. 1B), possibly due to an incomplete digestion of the DNA substrate. It may have resulted from small amount of restriction endonucleases present in the samples, as they were obtained from single bacterial colonies. Additionally, restriction endonucleases are lost during the purification process.

In contrast, when we used sonicated bacterial extract purified on phosphocellulose, we got a digestion pattern similar to the one obtained with commercial HindIII (Fig 1 D). This means that the purification on the minicolumn removed the nonspecific nucleases (Fig 1C, lane 5, 6 and 7).

Although sonication of bacterial cells is known to release various proteins including non-specific nucleases (Smith et al., 1976) our purification method allowed for their removal and enabled detection of site-specific nucleases.

Usually, to achieve high-purity restriction endonucleases, multistep purification on several matrices is used (Puchkova et al., 2002). However, screening for restriction endonuclease activity requires only partial purification.

We investigated the possibility of using various chromatography matrices. Hence, the crude extract obtained by sonication was also purified on heparin-sepharose, CM sephadex C-50 or blue-agarose. All of them proved to be effective in purifying HindIII restriction endonu-

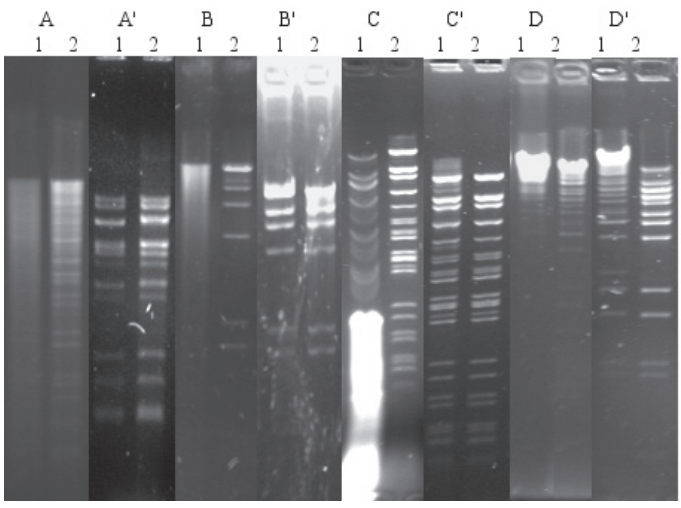

Figure 3. Bacteriophage I DNA digested with endonucleases extracted from various strains of bacteria.

(A, B, C, D) lanes: 1 crude bacterial extract, 2 extract after phosphocellulose purification. $\left(\mathbf{A}^{\prime}, \mathbf{B}^{\prime}, \mathbf{C}^{\prime}, \mathbf{D}^{\prime}\right)$ lanes: 1 extract after phosphocellulose purification, 2 commercial enzyme. Following strains of bacteria were used: $\left(\mathbf{A}^{\prime} \mathbf{A}^{\prime}\right)$ E. coli (EcoRV); (B, $\left.\mathbf{B}^{\prime}\right)$ E. vulneris (EcoVIII); (C, C') Citrobacter freundii (BspEI); (D', D') Klebsiella pneumoniae (BstEII). clease from the experimental strain of bacteria (Fig. 2A, $\mathrm{B}, \mathrm{C})$.

Our laboratory collection of Enterobacteriaceae contains several bacterial strains with high activity of nonspecific nucleases that preclude identification of site-specific endonuclease activity. Sonicated lysates of these bacteria were purified using the method described here. Bacteriophage $\lambda$ DNA was digested with obtained chromatography fractions. To confirm the digestion specificity, the patterns were compared to those obtained with commercial enzymes (Fig. 3). The restriction patterns of digested $\lambda$ DNA showed the presence of enzymes with the specificity identical with: EcoRV (Fig. 3A, A') in Escherichia coli, EcoVIII (Fig. 3B, B') in Escherichia vulneris, BspI (Fig. 3C, C') in Citrobacter freundii and BstII (Fig. 3D, D') in Klebsiella pneumoniae.

Another method for the removal of nonspecific nucleases before screening for restriction enzymes was described by Puchkova et al. (2002). Their method is based on the treatment of crude cell extracts with a temperature above $50^{\circ} \mathrm{C}$ for 10 minutes. Those authors have shown that in some strains of bacteria this procedure causes inactivation of nonspecific nucleases without reducing the activity of site-specific restriction endonucleases. Although this method is effective for strains producing thermo-resistant restrictases, during bacteria screening one is not aware whether the enzymes to be identified are resistant to a high temperature or not.

Another solution to the problem of nonspecific nucleases was published by Poch \& Somkuti (1993; 1995). They presented a simple method, where an affinity gel is placed directly in Eppendorf tubes containing sonicated and centrifuged bacterial extract and then washed with buffers. They showed that this procedure removed DNA, RNA and nonspecific nucleases. That is a quick and simple method, however, when high amounts of nonspecific nucleases are present, there is a possibility that the bacterial extracts will not be purified sufficiently.

The purification method described in the present publication is effective and avoids the pitfalls of the previously published protocols. The procedure is not only very easy, but also does not require any advanced equipment and thus can be used even in laboratories that are not specialised in protein purification. It is particularly useful when screening of numerous bacterial strains is performed. The method may be also applied for bacteria not belonging to the Enterobacteriaceae family (data not shown).

\section{Acknowledgements}

We would like to thank PhD Julianna Kurlenda from the Bacteriological Laboratory of the Koszalin Hospital for providing bacterial strains.

This work was supported by a grant from the University of Gdańsk (No. BW-L135-5-0101-9 to B.P).

\section{REFERENCES}

Arber W (1979) Promotion and limitation of genetic exchange. Science 205: 361-365.

Belavin PA, Dedkov VS, Degtyarew SKh (1988) A simple technique for detection of restriction endonucleases in bacterial colonies. Appl Bioch Microbiol (Russia) 24: 121-124.

Bickle TA, Krüger DH (1993) Biology of DNA restriction. Microbiol Rev 57: 434-450.

Edberg SC, Clare D, Moore MH and Singer JM (1979) Rapid identification of Enterobacteriaceae from blood cultures with the Micro-ID system. J Clin Microbiol 10: 693-697.

Edwards PR and Ewing W H (1972) Identification of Enterobacteriaceae. Burgess, Minneapolis 3rd edN. 
Greene PJ, Hevneker HL, Bolivar F, Rodriguez RL, Betlach MC, Covarrubias AA, Backman K, Russel DJ, Tait R, Boyer HW (1978) A general method for purification of restriction enzymes. Nuc Acids Res 5: 2373-2380.

Isenberg HD (2007) Clinical microbiology procedures handbook. Washington DC: Am Soci for Microbiol 2nd edn.

Kaida T, Ginting L, Kanda K, Murata A, Kato F (1999) Screening of type II restriction endonuclease from soil bacteria. Bull Fac Agr 84: $1-9$.

Krüger DH, Bickle A (1983) Bacteriophage survival: multiple mechanisms for avoiding the deoxyribonucleic acid restriction systems of their hosts. Microbiol Rev 47: 345-360.

Mruk I, Kaczorowski T (2003) Genetic organization and molecular analysis of the EcoVIII restriction-modification system of Escherichia coli E1585-68 and its comparison with isospecific homologs. Appl Environ Microbiol 69: 2638-2650.

Pingoud A, Jeltsch A (2001) Structure and function of type II restriction endonucleases. Nuc Acids Res 29: 3705-3727.

Poch MT, Somkuti GA (1993) Rapid screening of lactic acid bacteria for endonuclease activity. Biotechnol Tech 7: 781-784.
Poch MT, Somkuti GA (1995) Isolation of SagI, a new HaeIII isoschizomer from Streptococcus agalactiae. Appl Microbiol Biotechnol 43: 282-284.

Puchkova LI, Ushakova TA, Mikhailova VK, Serov GD, Krivopalova GN, Repin VE (2002) Testing and isolation of high-purity restriction endonucleases. Appl Biochem and Microbiol 38: 15-19.

REBASE http://rebase.neb.com

Roberts RJ (2005) How restriction enzymes became the workhorses of molecular biology. Proc Natl Acad Sci 102: 5905-5908.

Sambrook J, Fritsch E.T, Maniatis T (1989) Molecular Cloning: A laboratory manual. Cold Spring Harbor Laboratory Pr; 2nd edn.

Smith DI, Blattner FR, Davies J (1976) The isolation and partial characterization of a new restriction endonuclease from Providencia stuartii. Nuc Acids Res 2: 343-353.

Whitehead PR, Brown NL (1985) A simple and rapid method for screening bacteria for type II restriction endonucleases: enzymes in Aphanothece halophytica. Arch Microbiol 141: 70-74. 